\title{
An Investigation of Using Aerocon Block and M-Sand in Constructing Low Cost Housing
}

\author{
K.Jaiganesh ${ }^{1}$, S.Dinesh ${ }^{2}$ \\ ${ }^{1}$ (PG Scholar, Department of Civil Engineering, Sri Ramakrishna Institute of Technology, Coimbatore, Tamil \\ Nadu) \\ ${ }_{2}^{2}$ Assistant Professor, Department of Civil Engineering, Sri Ramakrishna Institute of Technology, Coimbatore, \\ Tamil Nadu)
}

\begin{abstract}
Low cost housing can be achieved by use of effective planning and project management, low cost materials, economical construction technologies and use of alternate construction methods available. . The selection of building materials should meet the needs of local circumstances to improve value of life for the most desired ones by building innovative structures or by refining existing structures. Various studies showed that a big variety of wall materials have been used in different building systems with traditional and modern construction methods, but only few of them (extruded clay bricks, hollow concrete blocks) have successfully been implemented in low-cost housing projects. The current era of real estate has ripened and the clay bricks and mortar are replaced with alternative construction materials like aerocon bricks. Innumerable properties in India are constructed with aerocon bricks and the method is rapidly flourishing. Some alternatives materials have already been used as a part of natural sand e.g. M-sand, fly-ash, slag limestone and siliceous stone powder are used in concrete mixtures as a partial replacement of natural sand. The main objective of this paper is to give detailed study on low cost building using aerocon block and M-sand.
\end{abstract}

Keywords: Aerocon block, Alternative material, Construction material, Eco-friendly building material, $M$-sand

\section{Introduction}

Low-cost housing projects are characterized by an increasing demand mainly due to urbanisation. The selection of building materials should meet the needs of local conditions to improve quality of life for the most needed ones by building new structures and/or by improving existing structures. Sustainability regarding urban housing intends to develop new approaches to manage human settlements and integrate energy and environmental issues. To achieve a sustainable housing project is required a balance of environmental, economical and social issues with technical issues. Findings show that up to $60 \%$ of the total cost of a lowincome housing project is allocated to engineering design and construction materials[2]. Moreover, walls constitute up to $50 \%$ of the total cost of materials and up to $45 \%$ of total construction time. Material origin, production techniques and labour requirements all have major impacts on the selection of wall building material. The analysis of particular local conditions will determine where materials are most suitable for their use. Furthermore, the time when materials and techniques were / are mostly used will determine whether they could be classified as traditional or contemporary[8]. The regularity of use will determine whether materials and methods could be classified as conventional or alternative.

Various studies showed that a big variety of wall materials have been used in different building systems with traditional and modern construction methods, but only few of them (extruded clay bricks, hollow concrete blocks) have successfully been implemented in low-cost housing projects[5-8]. Conventional materials (e.g. cement, steel, concrete) in low-cost houses constitute up to $98 \%$ of the materials used. Non-conventional materials (polymers, composites, recycled) have been left aside despite better thermal and condensation characteristics for local conditions. Alternative design including use of non-conventional materials have also been left aside despite reduction of construction time of more than 50\%. The current era of real estate has ripened and the clay bricks and mortar are replaced with alternative construction materials like aerocon bricks. Innumerable properties in India are constructed with aerocon bricks and the method is rapidly flourishing[15$18]$.

Now a day's sand is becoming a very scarce material, in this situation research began for inexpensive and easily available alternative material to natural sand. Some alternatives materials have already been used as a part of natural sand e.g. M-sand, fly-ash, slag limestone and siliceous stone powder are used in concrete mixtures as a partial replacement of natural sand[20]. However, scarcity in required quality is the major limitation in some of the above materials. Now a day's sustainable infrastructural growth demands the alternative material that should satisfy technical requisites of fine aggregate as well as it should be available abundantly. The main objective of this paper is to give detailed study on low cost building using aerocon block and M-sand. 


\section{Significance And Scope Of The Work}

Aerocon brick/block is a new generation building block that helps in creating sustainable buildings and infrastructure. The unique characteristics of these bricks like light-weight, fire resistance, etc., not only grabbed the attention of construction industry, but also made users more curious about its performance. Though there is hype in the industry about this new innovation, only few are clear about what exactly Aerocon is all about. So, in a view to help such folks, here is our small effort to put forward all the information related to Aerocon blocks. Aerocon bricks are Autoclaved Aerated concrete (AAC) blocks made with a mixture of cement, fly ash, lime, an aerated agent, and water[17].

\subsection{Types of Aerocon bricks:}

One interesting aspect of Aerocon brick is that it lets the user build the walls of with the thickness of his choice. Contrary to the wall made by traditional bricks, walls made with Aerocon bricks are thinner but are still sustainable. However, depending on different various needs of internal and external walls, Aerocon bricks are available in different sizes and varied thickness as follows,.

- Infill blocks: The size of the Infill Aerocon brick is $600 \times 600 \mathrm{~mm}$ and the thickness varies in the ranges of $75,100,125,150,200 \mathrm{~mm}$. The main advantage of Infill blocks is that they can easily replace $60 \%$ of the concrete in roof slabs and thus help in saving significant amounts of concrete, steel, labor, water, plaster etc. These blocks are especially suitable for building roofs in large column-free constructions.

- Jumbo blocks: Jumbo blocks are typically in the size of $600 \mathrm{X} 300 \mathrm{~mm}$, and thickness ranges from $75,100,125,150$, to $200 \mathrm{~mm}$. The unique large size of Jumbo Aerocon bricks results in the usage of much fewer bricks and hence less mortar is required. These bricks are more suitable for non-load bearing walls, multi-storeid buildings etc.

- Thermal blocks: These blocks are also called as Aerocool thermal blocks whose size and thickness is $300 \mathrm{X} 200 \mathrm{~mm}$ and $50 \mathrm{~mm}$ respectively. These blocks are ideal for roofing since they delay the transmission of heat flow and also help interiors remain warm during winters and cool during summers.

\subsubsection{Characteristics of Aerocon blocks:}

* Light-weight: The typical aircrete structure of Aerocon bricks resulted in light-weight blocks. Their weight is only one third the density of clay bricks which makes them easy to handle on-site. Reduced weight of the brick decreases the dead weight on the structure; hence Aerocon bricks are ideal for low load bearing soil and for seismic zones. Even for building additional floors in an existing building, Aerocon blocks are perfect choice as their less weight will not affect the stability of the structure. Using Aerocon bricks from the foundation stage of the building helps to save substantial amounts of concrete and steel.

* Fire resistance: Walls build with Aerocon bricks, with a minimum thickness of $100 \mathrm{~mm}$ can resist fire for up to four hours which make them the safe choice in construction. Especially for industries and companies, which are vulnerable to fire accidents, these blocks are of much help.

* Sound insulation: One more interesting characteristic of Aerocon bricks is their sound insulation. A good quality Aerocon brick can minimize the sound transmission up to 42 decibels. Reputed manufactures of Aerocon bricks do have a sound transmission class rating for their blocks, which made them ideal for wall construction in hotels, auditoriums, hospitals, etc., where sound insulation is quite essential.

- Thermal insulation: Due to the closed cell structure of the Aerocon blocks, they provide excellent thermal insulation. They help interiors to remain cooler during summer and warmer during winter which further aid the user to save electricity bills and thus help in conserving natural resources.

- Strength and durability: Aerocon bricks made with higher weight ratio help in building stronger and economical structure. As they remain unaffected by the environmental conditions they ensure longer life for the building.

* Perfect finish and dimensional stability: The autoclaving process used in the manufacturing of Aerocon bricks gives perfect dimensions to the blocks along with low tolerances. Dimensionally perfect blocks help in building uniform, thin walls with perfect finish.

* Consistent quality control: As brick making is in India is an unorganized market, the quality of regular bricks often vary based on the manufacturer. Hence consistent quality control is an issue with traditional bricks which is not an issue with the Aerocon bricks.

\subsection{M-Sand}

Manufactured sand is an alternative for river sand. Due to fast growing construction industry, the demand for sand has increased tremendously, causing deficiency of suitable river sand in most part of the word. Due to the depletion of good quality river sand for the use of construction, the use of manufactured sand has been increased. Another reason for use of M-Sand is its availability and transportation cost. Since this sand can be crushed from hard granite rocks, it can be readily available at the nearby place, reducing the cost of transportation from far-off river sand bed[20]. 
Thus, the cost of construction can be controlled by the use of manufactured sand as an alternative material for construction. The other advantage of using M-Sand is, it can be dust free, the sizes of $\mathrm{m}$-sand can be controlled easily so that it meets the required grading for the given construction.

\subsubsection{Advantages of Manufactured Sand (M-Sand) are:}

* It is well graded in the required proportion.

* It does not contain organic and soluble compound that affects the setting time and properties of cement, thus the required strength of concrete can be maintained.

* It does not have the presence of impurities such as clay, dust and silt coatings, increase water requirement as in the case of river sand which impair bond between cement paste and aggregate. Thus, increased quality and durability of concrete.

* M-Sand is obtained from specific hard rock (granite) using the state-of-the-art International technology, thus the required property of sand is obtained.

* M-Sand is cubical in shape and is manufactured using technology like High Carbon steel hit rock and then ROCK ON ROCK process which is synonymous to that of natural process undergoing in river sand information.

* Modern and imported machines are used to produce M-Sand to ensure required grading zone for the sand.

The study on builders"e provides knowledge to improve upon the marketing strategies, and to overcome the various problem areas identified during the study. In view of this, an experimental investigation was conducted on the alternative constructive materials such as M-sand and Aerocon brick.

\section{Materials And Methodology Of Investigation}

The main objective of this experimentation is to find out the effect of replacement of natural sand by manufactured sand with $0 \%, 50 \%$ and $100 \%$ on hardened properties of cement mortar. The experimental work includes the casting, curing and testing of specimens. Material properties are shown in Table 1.Mortar mix is prepared with proportion of 1:2, $1: 3$ and 1:6 with water cement ratio of 0.5 and 0.55 respectively. All of the experiments are performed in normal room temperature. The mortar ingredients namely cement and fine aggregate first mixed in dry state. Manufactured sand is used as a partial replacement to the natural sand then calculated amount of water is added and mix it thoroughly to get a homogeneous mix. Mortar is poured in the moulds layer by layer and compact thoroughly. Cubes are used for compressive strength test having size $7.06 \mathrm{~mm}(0.3 \mathrm{in}) \times 7.06 \mathrm{~mm}(0.3$ in $) \times 7.06 \mathrm{~mm}(0.3$ in) that are cured in water for 28 days and tested at 28 day's on Universal testing Machine (UTM).

AAC blocks are a relatively new phenomenon in Indian construction industry. Although first AAC blocks plant in India was set up in early 1970s by Siporex at Pune, it is only recently that manufacturing and usage of AAC blocks has reached sizeable number. Inspite of drastic growth in manufacturing of AAC products, fact is that market share of AAC products is very small compared to red clay bricks. There are various reasons for this, but that is a topic for another post. In this work we have provided a comparison between AAC blocks vs clay bricks and we let you be the judge for selecting the best product to suit your needs.

Table: 1.List of AAC blocks manufactures in India

\begin{tabular}{|l|l|l|l|}
\hline S.No. & Brand Name & Company & Location \\
\hline 1. & Aerocon & Aerocon India & Rajkot \\
\hline 2. & Aerocon & HIL & Golan \\
\hline 3. & Ascolite & Aswani Construcion Pvt Ltd & Surat \\
\hline 4. & BBEL & Avantha & Palwal (NCR) \\
\hline 5. & Xtralite & Ultratech & Hyderabad \\
\hline 6. & Renacon & Renaatus Procon Pvt Ltd & Chennai \\
\hline 7. & Reliconz & Reliconz Brixs Pvt Ltd & Hyderabad \\
\hline 8. & Ecolite & JVS Comastco & Sinnar \\
\hline 9. & JK SMARTBLOX & JK Lakshmi Cement & Jhajjhar \\
\hline 10. & Magicrete & Magicrete Building & Surat \\
\hline 11. & PRIME AAC & ECO-CARE Building Products Pvt Ltd & Vijayawada \\
\hline 12. & Siporex & B G Shirke Group & Pune \\
\hline 13. & EFCON & Phenix Procon Pvt. Ltd & Bawla \\
\hline 14. & Ecogreen & Ecogreen PVT Ltd & Gandhinagar \\
\hline 15. & Ecolite & JVS Comastco & Sinnar (Nashik) \\
\hline
\end{tabular}

\section{Result And Discussion}

\subsection{Manufactured Sand (M Sand)}

Only, sand manufactured by VSI crusher/Rotopactor is cubical and angular in shape. Sand made by other types of machines is flaky, which is troublesome in working. The Jaw crushers, are generally used for crushing stones in to metal/aggregates. Manufactured sand from jaw crusher, cone crusher, roll crusher often contain higher percentage of dust and have flaky particle.

\begin{tabular}{lll}
\hline DOI: $10.9790 / 1684-1403017075$ & www.iosrjournals.org & $72 \mid$ Page
\end{tabular}




\subsubsection{IS Code Provisions}

BIS Guidelines IS: 383-1970 for selection and testing of Coarse and Fine aggregates available. Generally, Sand is classified as Zone I, Zone II, Zone III and Zone IV (i.e. Coarser to Finer). There is sieve designation for each zone. Gradation is made in accord with the usage of the sand. There are testing sieves, consists of $4.75 \mathrm{~mm}, 2.36 \mathrm{~mm}, 1.183 \mathrm{~mm}, 600$ microns, 300 microns, 150 microns and a pan

\begin{tabular}{|c|c|c|c|}
\hline \multicolumn{4}{|c|}{ Table -2-Typical Sieve analysis: Comparison of River \& Manufactured Sand } \\
\hline IS Sieve & $\%$ of passing(River Sand) & $\%$ of passing (Manufactured Sand ) & Zone II (As per IS:383) \\
\hline $4.75 \mathrm{~mm}$ & 100 & 100 & $90-100$ \\
\hline $2.36 \mathrm{~mm}$ & 99.7 & 90.7 & $75-100$ \\
\hline $1.18 \mathrm{~mm}$ & 89 & 66.2 & $55-90$ \\
\hline 600micron & 60.9 & 39.8 & $35-59$ \\
\hline 300micron & 17.7 & 25.5 & $8-30$ \\
\hline 150micron & 3.1 & 9.9 & $0-20$ \\
\hline 75 micron & Max 3 & $\operatorname{Max} 15$ & Max 15 \\
\hline & Zone II & Zone II & \\
\hline
\end{tabular}

\begin{tabular}{|c|c|c|c|c|}
\hline \multicolumn{5}{|c|}{ Table - 3-Technical specification - comparison between Manufactured and River sand } \\
\hline $\begin{array}{l}\text { SI } \\
\text { No }\end{array}$ & Property & River sand & Manufactured sand & Remarks \\
\hline 1 & Shape & Spherical particle & Cubical particle & Good \\
\hline 2 & Gradation & Cannot be controlled & Can be controlled & \\
\hline 3 & Particle passing 75 micron & $\begin{array}{l}\text { Presence of silt shall be less } \\
\text { than 3\%(IS:383- } \\
\text { 1970)reaffirmed } 2007\end{array}$ & $\begin{array}{l}\text { Presence of dust } \\
\text { particle shall be less } \\
\text { than } 15 \%\end{array}$ & $\begin{array}{l}\text { Limit 3\% for uncrushed } \\
\& \text { limit } 15 \% \text { for } \\
\text { crushed sand }\end{array}$ \\
\hline 4 & Silt and Organic impurities & $\begin{array}{l}\text { Present (Retard the setting } \\
\text { \& Compressive Strength) }\end{array}$ & Absent & $\begin{array}{l}\text { Limit of } 5 \% \text { for } \\
\text { Uncrushed \& } 2 \% \text { for } \\
\text { Crushed sand }\end{array}$ \\
\hline 5 & Specific gravity & $2.3-2.7$ & $2.5-2.9$ & May vary \\
\hline 6 & Water absorption & $1.5-3 \%$ & $2-4 \%$ & Limit 2\% \\
\hline 7 & Ability to hold surface moisture & Up-to $7 \%$ & Up-to $10 \%$ & \\
\hline 8 & Grading zone(FM) & $\begin{array}{l}\text { Zone II and III } \\
\text { FM } 2.2-2.8\end{array}$ & $\begin{array}{l}\text { Zone II } \\
\text { FM } 2.6-3.0\end{array}$ & $\begin{array}{l}\text { Recommends Zone II } \\
\text { for Mass Concrete }\end{array}$ \\
\hline 9 & $\begin{array}{l}\text { Soundness(Sodium sulphate-ss } \\
\text { \& Magnesium sulphate -ms) (5 } \\
\text { cycles) }\end{array}$ & $\begin{array}{l}\text { Relatively less sound (Ex. } \\
>5 \text { ) }\end{array}$ & $\begin{array}{l}\text { Relatively sound } \\
\text { (Ex. <5) }\end{array}$ & $\begin{array}{l}\text { Limit } 10 \% \text { ss and } 15 \% \\
\text { ms }\end{array}$ \\
\hline 10 & Alkali Silica Reactivity & $0.002-0.01$ & $0.001-0.008$ & Limit $0.1 \%$ expansio \\
\hline
\end{tabular}

\begin{tabular}{|c|c|c|c|c|}
\hline \multicolumn{5}{|c|}{ Table - 3-Behaviour of Manufactured \& River Sand when used in Concrete: } \\
\hline $\begin{array}{l}\text { SI } \\
\text { No }\end{array}$ & Property & River sand & $\begin{array}{l}\text { Manufactured } \\
\text { sand }\end{array}$ & Remedies \\
\hline 1 & $\begin{array}{l}\text { Workability \& its } \\
\text { retention }\end{array}$ & $\begin{array}{l}\text { Good \& Good } \\
\text { retention }\end{array}$ & $\begin{array}{l}\text { Less \& Less } \\
\text { retention }\end{array}$ & $\begin{array}{l}\text { Control of fines \& apply water absorption } \\
\text { correction, use of plasticisers }\end{array}$ \\
\hline 2 & Setting & Normal & $\begin{array}{l}\text { Comparatively } \\
\text { faster }\end{array}$ & $\begin{array}{l}\text { Apply water absorption correction, use } \\
\text { retarders }\end{array}$ \\
\hline 3 & $\begin{array}{l}\text { Compressive } \\
\text { strength }\end{array}$ & Normal & Marginally higher & As shown above \\
\hline 4 & Permeability & Poor & Very poor & \\
\hline 5 & Cracks & Nil & $\begin{array}{l}\text { Tend to surface } \\
\text { crack }\end{array}$ & Early curing \& protection of fresh concrete \\
\hline
\end{tabular}

\begin{tabular}{|l|l|l|l|l|}
\hline \multicolumn{5}{|c|}{ Table-4-Cost comparison of Manufactured and River sand: } \\
\hline SI no & Location- Bangalore City & River sand & Artificial sand & Remarks \\
\hline 1 & Market rate & Rs 1100 per MT & Rs 600 per MT & $50 \%$ Cheaper \\
\hline 2 & In Concrete - Rs per Cum & Rs 770-880 & Rs 420-480 & Saving of Rs 350-400 per cum \\
\hline 3 & In Mortar(1:5) for 100kgs & Rs 198 & Rs 156 & $20 \%$ less \\
\hline
\end{tabular}

\subsection{Aerocon blocks}

Table -5-Comparison of Aerocon blocks with clay bricks.

\begin{tabular}{|c|l|l|l|}
\hline Serial & Parameter & Aerocon Blocks & Clay Bricks \\
\hline 1 & Basic Raw materials & $\begin{array}{l}\text { Cement, pfa/sand, gypsum and } \\
\text { aluminium as aerated compound }\end{array}$ & Top soil \& Energy \\
\hline 2 & $\begin{array}{l}\text { Structural saving due } \\
\text { to dead weight } \\
\text { reduction }\end{array}$ & $\begin{array}{l}55 \% \text { reduction in weight of walls. } \\
\text { Tremendous structural saving for high } \\
\text { rise buildings in Earth quake/ Poor soil } \\
\text { area }\end{array}$ & No additional saving \\
\hline 3 & Water absorption & Less than 20\% by volume & $20 \%$ by volume \\
\hline
\end{tabular}


An Investigation Of Using Aerocon Block And M-Sand In Constructing Low Cost Housing

\begin{tabular}{|c|c|c|c|}
\hline & capacity & & \\
\hline 4 & Productivity & Output $100 \%$ more than brick work & Normal \\
\hline 5 & Soil Consumption & $\begin{array}{l}\text { Zero soil consumption. Primary raw } \\
\text { material for AAC blocks is fly ash. This } \\
\text { fly ash is industrial waste generated by } \\
\text { coal-based thermal power plants. }\end{array}$ & $\begin{array}{l}\text { One sq } \mathrm{ft} \text { of carpet area with clay brick } \\
\text { walling will consume } 25.5 \mathrm{~kg} \text { of top soil. }\end{array}$ \\
\hline 6 & Fuel Consumption & $\begin{array}{l}\text { One sq ft of carpet area with AAC } \\
\text { blocks will consume } 1 \mathrm{~kg} \text { of coal. }\end{array}$ & $\begin{array}{l}\text { One sq } \mathrm{ft} \text { of carpet area with clay bricks } \\
\text { will consume } 8 \mathrm{~kg} \text { of coal. }\end{array}$ \\
\hline 7 & $\mathrm{CO}_{2}$ Emission & $\begin{array}{l}\text { One sq ft of carpet area will emit } 2.2 \mathrm{~kg} \\
\text { of } \mathrm{CO}_{2} \text {. }\end{array}$ & $\begin{array}{l}\text { One sq ft of carpet area will emit } 17.6 \mathrm{~kg} \text { of } \\
\mathrm{CO}_{2} \text {. }\end{array}$ \\
\hline 8 & Labour & $\begin{array}{l}\text { Organized sector with proper } \mathrm{HR} \\
\text { practices. }\end{array}$ & $\begin{array}{l}\text { Unorganized sector with rampant use of } \\
\text { child labour. }\end{array}$ \\
\hline 9 & Production Facility & State-of-the-art factory facility. & $\begin{array}{l}\text { Unhealthy working conditions due to toxic } \\
\text { gases. }\end{array}$ \\
\hline 10 & Tax Contribution & $\begin{array}{l}\text { Contributes to government taxes in } \\
\text { form of Central Excise, VAT and } \\
\text { Octroi. }\end{array}$ & $\begin{array}{l}\text { Does not contribute to government } \\
\text { exchequer. }\end{array}$ \\
\hline 11 & Size & $\begin{array}{l}600 / 625 \mathrm{~mm} \times 200 / 240 \mathrm{~mm} \times 100- \\
300 \mathrm{~mm}\end{array}$ & $225 \mathrm{~mm} \times 100 \mathrm{~mm} \times 65 \mathrm{~mm}$ \\
\hline 12 & Variation in Size & $1.5 \mathrm{~mm}(+/-)$ & $5 \mathrm{~mm}(+/-)$ \\
\hline 13 & $\begin{array}{l}\text { Compressive } \\
\text { Strength }\end{array}$ & $3-4 \mathrm{~N} / \mathrm{m}^{2}$ & $2.5-3 \mathrm{~N} / \mathrm{m}^{2}$ \\
\hline 14 & Dry Density & $550-700 \mathrm{~kg} / \mathrm{m}^{3}$ & $1800 \mathrm{~kg} / \mathrm{m}^{3}$ \\
\hline 15 & $\begin{array}{l}\text { Fire Resistance }\left(8^{\prime \prime}\right. \\
\text { wall })\end{array}$ & Up to 7 hours. & Around 2 hours \\
\hline 16 & Cost Benefit & $\begin{array}{l}\text { Reduction in dead weight leading to } \\
\text { savings in steel and concrete. }\end{array}$ & None \\
\hline 17 & $\begin{array}{l}\text { Thermal } \\
\text { conductivity } \\
(\mathrm{W} / \mathrm{m} . \mathrm{k})\end{array}$ & $0.132-1.151$ for $600 \mathrm{~kg} / \mathrm{m} 3$ & 0.184 \\
\hline 18 & Energy Saving & $\begin{array}{l}\text { Approximately } 30 \% \text { for heating and } \\
\text { cooling. }\end{array}$ & None \\
\hline
\end{tabular}

\subsection{M-Sand Environmental Impact}

\section{Summary And Conclusion}

The River sand lifting from river bed, impact the environment in many ways:

Due to digging of the sand from river bed reduces the water head, so less percolation of rain water in ground, which result in lower ground water level.The roots of the tree may not be able to get water.The rainwater flowing in the river contents more impurities. Erosion of nearby land due to excess sand lifting Disturbance due to digging for sand \& lifting, Destroys the flora \& fauna in surrounding areas The connecting village roads will get badly damaged due to over- loading of trucks, hence, roads become problem to road users and also become accidents prone. Diminishing of Natural Rivers or river beds, not available for future generations

\subsection{Aerocon block.-Ecofriendly}

The newly invented aerocon blocks are constructive products in the green building revolution. They are autoclaved, aerated, concrete blocks which are used for the construction of walls. The materials used in the production of these blocks are certified as green products and are environment friendly.

There are a number of problems involved in acquiring sand and bricks, besides the prices of these basic materials hiking up. As the traditional construction materials have a higher price the initiation of aerocon blocks acts as better substitutes with affordable prices. Due to these reasons the aerocon blocks are in great demand. Adding to it is the manufactured sand which also can be acquired without any hassle. In order to make use of these building materials more efficiently and make people aware of its benefits, an organised technique is required to promote them. It is very important that people are aware of the benefits of using the substitutes for construction materials.

According to various experts related to the real estate sector, the best environment friendly construction can be acquired through the usage of manufactured sand from stone quarries and brick substitutes. This will also avoid over-exploitation of natural resources like river sand and clay. Aerocon blocks these days are being used in incredible projects taken up by business tycoons and real estate builders. It is also necessary that the government should start promoting these environment friendly construction substitutes to boost market acceptance.

The government authorities have to put a stop to the mining of sand due to environmental concerns but the manual operations in the sand mining have increased its prices. The sand prices have increased since the last few months and so are the brick prices due to climatic changes. Owing to all these reasons it is better that the usage of the aerocon bricks be adopted. 


\section{References}

[1]. R.caponette\& G. De Francisc, (2013) "Ecological materials \& technologies in low cost building system"Int.Journal for housing sciences, Vol-37, pp-229-238

[2]. Swathik chowdhury, SangeetaRoy,(2013)"Prospects of low cost housing in India",Geomaterials, pp-60-65

[3]. David william Dobson, Amur Sourani , (2012), "Sustainable construction: Analysis of its cost \& benefits", American Jr of Civil Engg\& Arch, Vol-1, pp-32-38.

[4]. SenguptaNilanjan\& Roy Souuvanic, (2013), "Study of Appropriateness of cost effective building construction technologies in India", jrArchitEng Tech, Vol-2,pp-01-05.

[5]. F.Paceco-torgal, Said jalai, (2012), "Construction \& building materials, Construction \& building materials", 29, pp-512-519.

[6]. Tomas U Ganiron\& Mohammed Almaewae, (2014) "Prefabricated Technology in a modular house", Int. Jr of Advanced Sci\& Tech, Vol-73, pp-51-74

[7]. Vivian W.Y.Tam, (2011), "Cost effectiveness of using low cost housing technologies in construction", Procedia Engg, 14, pp-156160 .

[8]. Kuo-liang Lin, (2011), "Human resource allocation for remote construction projects", Jr of management in Engg, Vol-27, pp-13-20.

[9]. Iwuagu ben ugochukwu, Iwuagu ben chioma. M, (2015), "Local building materials : affordable strategy for housing the urban poor in Nigeria", Procedia Engineering, 118, pp-42-49.

[10]. Mohammad sharifzami, Angela lee, (2009), "Economic benefits of contemporary earth construction in low cost urban housing state of the art review", Jr. of building appraisal, Vol-5, pp-259-271.

[11]. Bredenoord J, (2016), "Sustainable Housing and Building Materials for Low-income Households", Jr ArchitEng Tech 5: 158, pp01-09.

[12]. PreetpalSingh, Gurjeet Kumar, (2016), “Low Cost Housing: Need for Today’s World”, International Journal of Engineering Research-Online A Peer Reviewed International Journal, Vol-4, Issues-3, pp-240-249.

[13]. Felix Raspall, Mohit Arora,(2014) "Building from End-of-Life: An Alternative Approach for Low-Cost Urban Housing”,Ethzurich, pp-01-08.

[14]. RinkuTaur, Vidya Devi T (2009), "Low Cost Housing”, ACSGE-2009, Oct 25-27, pp-01-11.

[15]. B Bakhtyar, A Zaharim, K Sopian, S Moghimi, (2013), "Housing for Poor People: A Review on Low Cost Housing Process in Malayasia", Wseas Transactions on Environment andDevelopment, Issue 2, Volume 9, pp-126-136.

[16]. Dhiraj B Tapkir, Nikhil R Mohire, Pratik N Zurunge, Siddharth R Sonsale4, A.W Dhawale(2016), "Study and Analysis of low cost housing based on construction techniques", International Journal of Research in Engineering and Technology , Volume: 05 Issue: 05 , pp-146-148.

[17]. John M.Hutcheson, (2011), "Project Management of Low Cost Housing in Developing Countries", Journal Architectural Science review, Vol-28, pp 8-11.

[18]. Ali HaiderJasvi, D.K. Bera, (2015), "Sustainable Use of Low Cost Building Materials inthe Rural India", International Journal of Research in Engineering and Technology Volume: 04 Special Issues: 13, pp-534-547.

[19]. Priyanka A. Jadhav, Dilip K. Kulkarni, (2013), "Effect of replacement of natural sand by manufactured sand on the properties of cement mortar", International Journal Of Civil And Structural Engineering, Volume : 3, PP-621-628.

[20]. P. P. Bhangale, Ajay K. Mahajan, (2015), “ Cost Reduction through Cost Effective Construction Techniques”, International Journal of Science and Research, volume : 4 , issue :2, pp-2167-2169. 